\title{
Banking Responsibility and Liability for the Environment: What Are Banks Doing?
}

\author{
by \\ AnTONy L.T. MCCAMmon, ${ }^{*}$ Representative \\ Cater Allen Bank (Jersey) Limited, \\ Minervastrasse 117, 8032 Zürich, Switzerland.
}

\section{INTRODUCTION}

$\mathrm{E}^{x}$ xtensive press coverage has been given recently to setpiece battles that are being waged by a (somewhat fatigued?) 'green' movement against alleged perpetrators of newsworthy crimes against the environment. In popular terms, the world has become a 'Sherwood Forest', in which noble ecological 'Robin Hoods' and 'Maid Marions' wage heroic wars against naughty, polluting, 'Sheriffs of Nottingham'. And very good fun it is, too. Even countries are joining in; Brent Spar hogged the headlines for a week or too, but now it is the turn of the wicked one in France and his mean team, who have continued 'testing' more nuclear devices in the South Pacifict. The Chinese, masters of the inscrutable, have been doing the same sort of thing at Lop Nor (as well as rocket tests over the ocean north of Taiwan), but are for some reason not deemed to be nearly so wicked; 'massive condemnation' has a different meaning in the Middle Kingdom. Stolid Little-John of London somehow always finds himself on the wrong side, which gives an added twist to the tale. And if a banker, with his allegorical travelling-chest of ill-gotten gains, ever rides through the forest, he is - even now - fair game for any of Robin's merry men. How, then, can a banker possibly play a useful part in a constructive debate on the twin subjects of environment and development?

In an attempt to elucidate the attitude of the banking fraternity towards Man and Nature's environment, the present Author received detailed responses from more than 300 commercial, investment, and merchant, banks, as well as bank associations, around the world, which, in one way or another, have contributed to environmental and/or developmental initiatives in the last few years. Mixed in among these names, there are even a few central banks which have provided material.

The long list of responses to his questionnaire, sent to seven hundred and fifty institutions world-wide, the Author has tabulated with pertinent details of the banks, etc., involved. The resulting table $\$$, largely made up of banks which have agreed to take part in surveys that address this subject, is certainly not exhaustive; the names of some 2,000 US banks which have provided feedback in other surveys (summarized below) are, for example, not included. Those financial institutions mentioned in the table should be seen, nevertheless, as representative of a

* Over 30 years in international banking - mainly with the Bank of London \& South America, and Lloyds Bank, but now with the Cater Allen Group - and having represented the Foundation for Environmental Conservation at UNCED, the Author has developed a specialist interest in the twin fields of Environment and Development, from a banker's point of view, in which he has latterly become a widely-respected leader. - Ed.

$\dagger$ We cannot help thinking that the latest spate of earthquakes and other calamities may be connected in some way with underground nuclear testing in a planet that is being deprived all the time of enormous amounts of 'fossil fuels'. - Ed.

$\S$ The Author (address above) will be pleased to send copies of his unique table to interested readers, exigences of time and space having precluded its publication as an annex to this paper - most unfortunately. - Ed. growing number of banks that are making serious efforts to understand their respective functions in local environment and development, so as to be able to reconcile them sensibly and constructively with their breac-and-butter business, while not losing sight of their competitive edge and civic - ultimately global - responsibility. A bankers' lobby is surprizingly cohesive!

Multilateral finance and regional development (functions of, for example, the World Bank, the African Development Bank, and the European Investment Bank) are not the essential themes here, although the majority of these institutions have developed their own environmental codes and practices. The scene for this paper was in fact set at an International Workshop on "Banking and the Environment' $¥$, chaired by the present writer, that was held in Zürich on 29 November 1991, when Dr Robert J.A. Goodland, of the World Bank, enlarged on the theme 'Environmental Priorities for Commercial Banks'. On that occasion, the valuable - if painful - experiences of the World Bank during its so-called 'greening' period were set down as milestones for independent lending institutions. At the same time, Dr Goodland cited various codes of ethics (including the Business Charter for Sustainable Development - see below), which, in the last four years, have proved to be valuable signposts for the banking industry when pursuing the same worthy objective of environmental concern and effective action. Elsewhere, he outlined the World Bank's environmental assessment (EA) procedures and policies for achieving environmental prudence, and predicted '... a similar move in financial institutions' (Goodland, 1992).

Mention is also made below of one study, drawn up on behalf of the European Bank for Reconstruction and Development (EBRD) with the aim of providing environmental training for bankers in Central and Eastern Europe. Brokers of debt instruments of developing economies are felt to be outside the scope of this paper. (It is here argued that the interests of these institutions differ essentially from those of the issuer countries: external holders of such 'securities' with an uncertain due date are usually looking for appreciation of their investment, while issuers, ironically, generally only benefit from this market when the price drops sufficiently for repurchase to become feasible or desirable; Nicaragua, for example, is currently offering to buy back its recognized commercial debt of US\$1.3 thousand millions for eight cents in the dollar (Financial Times, 1995). Positions in developing country debt instruments are seldom held by the brokers themselves.)

The thrust of this paper is, rather, towards sovereign (i.e. country) responsibility and liability, and local funding (see McCammon, 1994, to which this paper should, to a large extent, be considered a sequel).

The learning process towards such local funding responsibility, with local banks occupying a key role, is

$\ddagger$ See our account published on pp. 86-7 of the Spring 1992 issue of this Journal. —Ed. 
seen as of the utmost importance in fulfilling that part of Agenda 21 which reads: "In general, the financing for the implementation of Agenda 21 will come from a country's own public and private sectors...' (the present writer's italics) (UNCED*, 1993).

\section{FleEt FaCtORS THE SPUR}

Banks in the USA have made it their business for some years to stay abreast of environmental legislation in view of ruthless application of the concepts of lender liability under the Comprehensive Environmental Response, Compensation, and Liability Act (CERCLA*). Interest had been quickened by the notorious (in banking circles) case of US v. Fleet Factors Corporation, which was the first to establish lender liability in the context of United States Environmental Law (Wilde Sapte, 1991).

Fleet Factors, a large regional bank, had entered into a 'factoring' agreement with Swainsboro Print Works, under which funds were advanced against collateral of accounts receivable as well as a security interest in the latter's textile facility with all its equipment, inventory, and fixtures. In 1979 Swainsboro filed for bankruptcy but the factoring agreement continued with court approval. In 1981 the bank ceased to advance funds, foreclosed on its security interest, and hired a company to auction the collateral and (allegedly) to remove all unsold equipment. Two years later the Environmental Protection Agency (EPA) found toxic chemicals and asbestos on the property. The 11 th Circuit Court of Appeals determined that Fleet Factors was liable for the costs of cleaning up contaminated land where it, as the lender, participated 'in the financial management of a facility to a degree indicating a capacity to influence the Corporation's treatment of hazardous waste'.

In the long shadow of the Fleet Factors case, the following statistics became available from an environmental survey which covered 1,741 of the 9,000 US credit institutions in early 1991:

- $13.5 \%$ of those banks which were approached had already been obliged to pick up the costs of de-pollution of fixed assets held as security for customer loans;

- $88 \%$ had already modified their credit procedures to take in environmental considerations;

- $62.5 \%$ had turned down credit requests on environmental grounds;

- $45.8 \%$ had discontinued loans to certain businesses because of fear of environmental liability; and

- $13.5 \%$ had incurred clean-up costs on property held as collateral.

No less than eight categories of risk to financial institutions from environmentally contaminated property had been listed in a 1989 circular from the US Federal Home Loan Bank Board (American Bankers Association, 1991).

So yes, well before the United Nations Conference on Environment and Development (UNCED) was held in Rio de Janeiro in 1992, American banks were enmeshed in the subject.

\section{Business Charter for Sustainable DeVElopment}

Early in 1990, 20 major US corporations joined forces to set up the Global Environmental Management Initiative

* A helpful list of Acronyms and Abbreviations is given at the end of the present paper, before the References. -... Ed.
(GEMI) in Washington, DC. The Business Charter for Sustainable Development, with the drafting of which GEMI and its members were closely associated, was adopted by the 64th Session of the International Chamber of Commerce (ICC) Executive Board in November 1990 and first published in April 1991*. In it the ICC called upon enterprises and their associations to use the 'Principles for Environmental Management'* as a basis for pursuing the protection and improvement in the quality of the environment (Goodland, 1992 Annex 7). GEMI maintained close involvement with the Business Charter and, with a view to the latter's implementation, published its own Environmental Self-assessment Program (ESAP) in September 1992.

Between May 1992 and January 1995, companies and national business organizations which had informed the ICC of their support for the Business Charter, more than doubled in number - from 909, including 28 financial institutions and two banking associations, to 1,840 , including 76 financial institutions, subsidiaries, and branches, and the same two banking associations. It should be pointed out that Malaysian names make up over one-third of the total number of companies (748), and nearly one-half of the number of banks (36), following an unusually successful campaign of the Malaysian International Chamber of Commerce and Industry (MICCI); over $90 \%$ of MICCI members are Business Charter supporters.

\section{BANKER's CONCERNS BEFORE UNCED}

In April 1992, just before the Rio conference, a survey questionnaire was sent out to 750 banks world-wide by the present writer. Initial results were then taken to Rio ${ }^{\dagger}$ and discussed wherever possible with UNCED delegates as well as certain NGO representatives at the Global Forum. In the euphoria of the moment, at a time when hopes were pinned on the Global Environmental Facility (GEF), and developed countries were speaking comfortably of attaining the UN target of $0.7 \%$ of their GNP for official development assistance (McCammon, 1994), it was not easy to make a case that commercial banks should be involved in the process of environmental recognition. The introduction of a concept that environmental impact assessment (EIA) should be carried out before disbursement could take place was perhaps also untimely. Nevertheless the point was emphasized.

From 75 detailed responses to the Author's questionnaire, including only two from the USA and not one from the former Soviet Union, it could be seen that:

- $23 \%$ considered that they had a deep commitment to the environment, in some cases supported by an environmental code;

- $40 \%$ had already taken certain internal measures;

- $17 \%$ already had environmental coordinators, and a further $11 \%$ planned to appoint one shortly;

- $19 \%$ used environmental impact assessment (EIA) of some kind; and

* See also Business Charter for Sustainable Development: Principles for Environmental Management, by International Chamber of Commerce, Environmental Conservation, 20(1), pp. 82-3, 1993.

Where the Author represented the Foundation for Environmental Conservation. - Ed. 
- $11 \%$ considered that banks in their respective countries could be made legally liable for environmental damage by borrowers.

Lest it be thought that these responding banks were focusing only on their internal procedures, with a view to minimization of their own environmental risks, here is a summary of the — widely altruistic - replies to the question, asked in the same questionnaire:

'From a Bank(er)'s point of view, what are the three most important ecological/environmental concerns of your country?'

It should be remembered that this question was posed in April 1992; the answers - here classified by country should therefore be seen in a historical (i.e. pre-UNCED) context. Remember, too, that the responses - however subjective they may seem - were offered, not by environmentalists or other scientists, but by bankers and bank employees around the world. While no nuance was intended in the question, it is interesting to note that some respondents read the word 'concerns' as' meaning 'worries', but others as 'measures to be taken'. The replies are given as far as possible verbatim, where necessary after translation, followed by the name of the country or other geographical unit whence they came. All are as of April 1992.

Atmosphere:

- 'Greenhouse Effect' and stratospheric ozone depletion Australia, Bahrain, Fij, Transkei

- Air pollution Australia, Bahrain, Canada, Ghana, Greece ('cities'), Hungary, India, Indonesia, PhilipPines, Portugal, Poland, South Africa, Switzerland, Taiwan, Tunisia, WESTERN SAMOA

- Avoid/reduce air pollution NetherLANDS, SwitzerLand

Ban on use of CFCs in industry CROATIA, USA

- Carbon Poland

- Sulphur dioxide Poland, USA

- Insufficient control over industrial pollution SOUTH AFRICA

- Avoid atmospheric contamination of cities COSTA RICA

- Air pollution due to oil fires KUwAIT

- Carbon monoxide gases from motor vehicles OMAN

Flora \& Fauna:

Protection of the natural environment Greece, TAIWAN

- Plant/forest destruction Ghana, Guatemala, PhilipPines

- Conservation of animals such as jacaré [alligator] PARAGUAY

- Social forestry and tree plantation INDIA

- Protection of endangered bird and animal species from being hunted BELIZE

Land:

- Acid rain Hungary

- Avoid pollution of land WeStern SAMOA

- Avoid soil pollution NETHERLANDS

- Soil conservation/scientific management INDIA

- Earth contamination IsLe of MAN, Poland, SOUTH Africa, SWITZERLAND ('Bodenbelastung'), UK

- Degradation, erosion "due to overgrazing by large cattle herds/ poor agricultural practices' Australia, Botswana, SOUTH AFrica, SWAZILAND

- Wildfires (Veld burning): burning of forests and grass in dry season SWAZILAND

- Unmanaged deforestation MALAYSIA

- Deforestation/forest clearing/burning and consequences BOLIvia, Brazil, Honduras, India, Indonesia, Nepal, Nigeria, SURINAM, ZAMBIA

- Accelerated depletion of forests for economic reasons TURKEY

- Conserve forests/enhance reforestation COSTA RICA, PARAGUAY, WESTERN SAMOA

- Land clearance, both state and private development SRI LANKA

- Insufficient control over industrial pollution SOUTH AFRICA

- Salt/erosion Australia

- Minimizing use of dangerous chemicals in agricultural industries SURINAM

- Desert encroachment NigeriA

Gully erosion NigERIA
Natural Resources:

- Economic development at the expense of rapid and uncontrolled depletion of natural resources FIJI

- Depletion of natural resources LESOTHO

Preserving natural resources THAILAND

Preservation of natural environment BeLIzE

Nuclear:

- Testing and toxic waste dumping in the Pacific FIJI

Ban on construction of nuclear plants CROATIA

- Breakdown risks ('Störfallrisiken') SwITZERLAND

Ocean:

- Pollution Bahrain, Ghana, Tunisia ('tourist destination'), WESTERN SAMOA

- Treatment and protection of the Adriatic Sea and all waters against pollution CROATLA

- Throwing of poisonous wastes into Karadeniz and Bosphorus without permission TURKEY

- Marine pollution due to oil-spills Kuwart, OMan

- Protection of the coral reef BELIzE

Power/Energy:

- Energy SwitzerLand

- Energy crisis PHILIPPINES

- Investment in desulphurization equipment for power stations CZECHOSLOVAKIA

- Efforts to build thermic power-station on Akdeniz shores TURKEY Internal energy conservation measures SPAIN

Air conditioning systems SPAIN

- Support of internal energy conservation measures ANGOLA

- Dependence on coal for electricity SouTH AFRICA

Waste:

Sewage/waste disposal Greece, India, IsLE of MAN

- Hazardous and solid waste disposal Bolivia, CANADA, INDIA

- Management of human waste/protection of common sources of water from pollution INDIA

- Disposal of plastic bags/bottles, beer/soft-drink cans, by motorists and bus passengers SWAZILAND

- Investment for waste recycling and refuse treatment systems CZECHOSLOVAKIA

- Extensive use of polyethylene products TURKEY

- Municipal sewage POLAND

- Industrial wastes (disposal) POLAND, SRI LANKA, TAIWAN

- Avoid waste NeTHERLANDS

- Waste management ('prepare' projects) AUSTRIA

Water (fresh):

- Increasing pollution of (ground) water (supplies) BAHRAIN, Botswana, India, Indonesia, Oman, Poland, Portugal, SOUTH AFRICA, TAIWAN

- Shortage of water resources HondurAS

- Water conservation/scientific management BoLIVIA, INDIA

- Water crisis PHILIPPINES

- Investment for the improvement of the quality of water CZECHOSLOVAKIA

Water quality USA

- Clean surface and ground-water CANADA

- Pollution of waterways INDIA, SRI LANKA

- Reducing pollutants in water THAILAND

- Conservation of water-tables ('cuencas hidrograficas') COSTA RICA

- Renovation of sewage control ('Canalization') to prevent drinking-water pollution AUSTRIA

- Pollution of water-table due to oil-well damage KuwarT

Drought Guatemala

- River pollution GuATEmala

- Unsafe drinking-water INDIA

- Silt accumulation in rivers/reservoirs INDIA

General:

- Pollution Brazil, Honduras

- Lack of maintenance of infrastructures once built BOTSWANA

- Noise Portugal, Costa Rica

- Profit UK

- Productivity Lesotho, UK

- Social/public awareness/responsibility TAIWAN, THAlland, UK

- Balance between business and the environment, especially the challenge of creating wealth for the poorer sectors of society (world-wide) without damaging the environment USA

- Previous contamination/observe production process AUSTRIA 
- Support of an environmental code ANGOLA

- Prevent ecological disruption or damage WeSTERn SAMOA

- Environmental feasibility studies by law AUSTRIA

- Traffic Bahrain, Germany ('Fahrzeugsdichte'), SwitzerLand

- Concentration of industry GERMANY

- Population concentration GERMANY ('Bevölkerungsdichte')

- Spearheading development re.protection, management, and improvement of the environment SRI LANKA

- Equitable means of making the polluter pay ISLE OF MAN, UK

- Effect on health in general LESOTHO

- Process production techniques UK

- Industrial pollution NigerIA, ZAMBIA

- Industria' location NEPAL

- Use of pollution elimination and reduction technologies in existing industrial units INDIA

- Lack of local funding and of people's awareness for environmental improvement NEPAL

- Proper housing and schooling Surinam

- Assist or award enterprise to execute environmental protection project TAIWAN

- Let environmental protection become the prime recognition of banking circles TAIWAN

- Food preservation, transport, and distribution INDIA

- Lack of civic sense/education INDIA

- Oil pollution TRANSKEI

- High level of production ('Überhöhtes Konsumniveau') with environmentally inefficient production methods SWITZERLAND

One wonders how replies would differ if the questions were posed again today.

\section{UNEP STATEMENT}

At the time of UNCED, the initial results of a UNEP banking initiative were also becoming available. Entitled UNEP - Banking and the Environment - A Statement by Banks on the Environmental and Sustainable Development, it read as follows:

\section{Foreword}

We, the undersigned, believe that human welfare, environmental protection, and [ecologically] sustainable development, depend on the commitment of governments, businesses, and individuals. We recognize that the pursuit of economic growth and a healthy environment are inextricably linked. We further recognize that ecological protection and sustainable development $^{*}$ are collective responsibilities and must rank among the highest priorities of all business activities, including banking. We will endeavour to ensure that our policies and business actions promote sustainable development: meeting the needs of the present without compromising those of the future.

\section{1) General Principles of Sustainable Development}

(1.1) We believe that all countries should work towards common environmental goals.

(1.2) We regard sustainable development as a fundamental aspect of sound business management.

(1.3) We believe that progress towards sustainable development can best be achieved by working within the framework of market mechanisms to promote environmental protection. We believe that there is a role for governments to provide the right signals to individuals and businesses to promote behavioural changes in favour of effective environmental management through the conservation of energy and natural resources whilst promoting economic growth.

(1.4) We regard a versatile, dynamic financial services sector as an important contributor towards sustainable development.

(1.5) We recognize that sustainable development is a corporate commitment and an integral part of our pursuit of good corporate citizenship. We are moving towards the integration of

* Supposedly regardless of whatever it may mean: there are said to be more than 70 definitions of this catchy term. - Ed. environmental considerations into banking operations and business decisions in a manner which enhances sustainable development.

\section{2) Environmental Management and Banks}

(2.1) We subscribe to the precautionary approach to environmental management, which strives to anticipate and prevent potential environment degradation.

(2.2) We expect, as part of our normal business practices, that our customers [will] comply with all applicable local, national, and international, environmental regulations. Beyond compliance, we regard sound environmental practices as one of the key factors demonstrating effective corporate management.

(2.3) We recognize that environmental risks should be part of the normal check-list of risk assessment and management. As part of our credit risk assessment,* we recommend environmiental impact assessments whenever appropriate.

(2.4) We will, in our domestic and international operations, endeavor to apply the same standards of environmental risk assessment.

(2.5) We look to public institutions to conduct appropriate, up-to-date and comprehensive environmental assessments in ventures with them, and to share the results of these assessments with participating banks.

(2.6) We intend to update our management practices - including accounting, public affairs, employee communications, and training - to incorporate relevant developments in environmental managements. We encourage banking research in these and related issues.

(2.7) We will seek to ensure that, in our internal operations, we pursue the best practices in environmental management including energy efficiency, recycling, and waste minimization. We will seek to form business relations with suppliers and subcontractors who follow similarly high environmental standards.

(2.8) We support and will develop suitable banking products and services designed to promote environmental protection, wherever there is a sound business rationale.

(2.9) We recognize the need to conduct internal environmental reviews on a periodical basis, to measure our operational activities against our environmental goals.

\section{3) Public Awareness and Communication}

(3.1) We will share information with customers, as appropriate, so that they may strengthen their own capacity to reduce environmental risk and promote sustainable development.

(3.2) We will foster openness and dialogue relating to environmental management with all relevant audiences, including governments, clients, employees, shareholders, and the public.

(3.3) We recommend that banks develop and publish a statement of their environmental policy and periodically report on its implementation.

(3.4) We ask the United Nations Environment Programme to assist the [banking] industry by providing, within its capacity, information relating to [ecologically] sustainable development.

(3.5) We will periodically review the success in implementing this Statement, and will revise it as appropriate.

(3.6) We encourage other banks to support this Statement.

As of January 1995, 66 banks around the world had put their signature to the above Statement as indicated in the detailed table compiled by the Author of this paper and available from him as indicated in the lowest footnote on the opening page of this paper.

\section{EBRD INITIATIVE}

In the autumn of 1993, GHK [Gilmore, Hankey \& Kirk] International of Birmingham, England, UK, were set the

* The standard banking procedure(s) in the measurement of credit worthiness when, say, a loan facility is being considered. - Ed. 
task, by the European Bank for Reconstruction Development (EBRD), of putting together an environmental issues handbook to be made available to banks in Central and Eastern Europe. For this purpose a report was drawn up (GHK International Ltd., 1994) which reviewed current environmental practices of banks in Europe, the US, and SE Asia. Fifty-six banks took part in the survey (including two each from Hungary, the Czech Republic, and Slovakia), as well as four International Financial Institutions.* Findings included the following:

- While exposure to environment-related liabilities on loan activities is increasingly common, exposure to such liabilities on equity investments is far less so;

- Banks are not generally using higher capital balances to cover environmental risk;

- Banks are increasingly seeing the benefits of due environmental diligence, with some institutions responding with a more risk-averse lending policy than formerly, while others are sharpening their skills in risk identification;

- Direct commercial benefits are more apparent in administration ('housekeeping') and public relations than other connexions, although 'core' banking implications are also emerging;

- US banks are a long way ahead of their European counterparts in the application of environmental-risk management procedures, with Swiss and German banks catching up fast.

- Among Central and Eastern European banks, exposure to environmental risk in loan portfolios is widespread in view of the traditional large-scale lending to the state sector. Practices aimed at remedying the situation lag well behind the North American and Western European models, but are marginally ahead of the average in the Czech Republic.

\section{UNEP SURVEY}

In January 1995, results were published of a UNEP global survey (undertaken jointly with Salomon Inc., New York) on the subject of 'Environmental Policies and Practices of the Financial Services Sector' (UNEP, 1995). Ninety of the 177 banks approached responded*; the only region which was completely unrepresented was South America. Many of the GHK conclusions were confirmed, although the formulation of questions had been slanted differently.

It was immediately noticeable that European banks were ahead of their North American counterparts in pursuing environment-related investment and lending opportunities, despite the US banks' comparatively early initiation into the subject. It should be added here, however, that North American institutions appeared to place the greatest focus - perhaps defensively - on EIA, environmental credit risk analysis or audit, or adding environmental criteria to the credit review process. Among other key findings of the survey were the following:

- $31 \%$ of respondents said they lend to, or invest in, environment-related firms today, while $57 \%$ more said they expect to do so within 15 years. European financial institutions place the most emphasis on this, followed by Asian institutions.

* See the detailed Table compiled by the Author and available from him as indicated in the lowest footnote in the left-hand column on page 297 . - Ed.
- $55 \%$ of respondents stated that they include specific environmental covenants and conditions that directly assess a borrower's environmental performance and activities within their basic contractual agreements.

- $50 \%$ of respondents continue to monitor environmental risks, at least once a year, when once funding has been committed.

- $33 \%$ of respondents felt that they are not subject to any regulation or guidelines (i.e. legislative, governmental, non-governmental, or multilateral bank).

- $67 \%$ of respondents predicted that governmental requirements in this sector will get stricter within the next five years.

- All respondents predicted that environmental issues will receive more attention and become increasingly integrated with core-business activities over the next 15 years.

Of the conclusions reached by the analysts of this survey, two stand out:

1. 'Environmental risk management, from a debt-financing perspective, has become accepted by banking leaders as part of the basic credit process in virtually all industrial countries and most transitional economies' [the reader receiving the detailed Table* will note from it, however, that only one Russian bank took part in the UNEP survey].

2. 'Involvement with environmental activities crosses all geographic regions of the world's industrialized economies. North American institutions are the most focused on risk-management processes and tools, and European institutions are leading the way in identifying environmentally-related new business opportunities.'

\section{ROUNDTABLE For The BIOSPHERE?}

The most recent UNEP initiative (Second Roundtable Meeting on Banking and the Environment, held at EBRD, London, England, UK, during 30-31 October 1995, proceedings as yet unpublished) brought over 60 banks and bankers' associations* together with environmental experts and pressure-group representatives. Papers presented and their sources included the following (provisional information kindly supplied by UNEP, Geneva):

- 'Private Sector Investment Flows and the Environment (...)' (Yale Center for Environmental Law and Policy);

- 'Greening the Financial Sector' (British Bankers' Association);

- 'The Role of Banks in the Present and Future Interplay Between Governments, Industry, and Publics, on the Global-warming Threat' (Greenpeace);

- 'Risk and Yield of Green and Environmental Stock Funds' (Swiss Credit Bank);

- 'Risk Management in the Investment Process' (Bank Handlowy w Warszawie); and

- 'Expanding the Financial Market's Information Base on Environmental Exposures' (World Resources Institute).

According to a 'very rough first draft' of the Meeting Report of this UNEP event, 'the need to move beyond liability management that is purely regulation-driven emerged as the most important issue (...)'. This trend was to be interpreted in two senses: '... towards a real acceptance 
of environmental responsibility, and (...) towards recognizing the positive investment opportunities within the environment'. This, taken together with the fact that officers with such wide-ranging interests are now sitting down at the same table, will be music to the ears of all who are striving to couple simple banking creeds with the survival of The Biosphere.

\section{BASES FOR UNDERSTANDING}

The present Author's ongoing discussions with environmental officers of large Swiss banks, and involvement in bank/environment seminars in Germany (one, at the Bank Akademie in Frankfurt, having been put on by the students themselves) seem to indicate that these two countries - with the USA - are indeed at the forefront of developments in this field. As might be expected, German banks are going about the task in an admirably methodical way, focusing their attention primarily on internal, environment-oriented rationalization; the mundane activities of weighing paper, calculating food-waste, and plotting heating patterns, for example, are corner-stones of the whole. BankAmerica, Royal Bank of Canada, and Swiss Bank Corporation (Goodland, 1992 Annex 8), were among the first financial institutions to lay down, and make public, their own environmental codes.

There is, however, little doubt that banks in other regions, too, are at least sitting up and taking notice. Financial institutions in other Northern European countries (United Kingdom and those of Scandinavia), Australasia, the Far East (Hong Kong, Malaysia), and Southern Africa (Botswana, Namibia, South Africa, Zimbabwe) have developed their own approaches and designed their own EIAs. A goodly number of banks in Latin America and even Oceania are also joining the fray.*

Anticipation of legal requirements is the name of the game. Banks and bankers' associations in the UK, Canada, and Australasia, have forcibly adopted the view that sensible, concerted action by themselves will, hopefully, render legislation unnecessary. Happily the chairman of Britain's National Westminster Bank currently heads the British Government's Advisory Committee on Business and the Environment (ACBE). After some initial scepticism, the British Bankers' Association has become increasingly involved with UNEP and the Intergovernmental Panel on Climate Change (IPCC).

Environmental briefing for bankers - at least in developed countries - is now a fact of life. Responsible for the environmental affairs of the Union Bank of Switzerland - the largest Swiss lending institution - is a young man whose dissertation at the Hochschule St Gallen, entitled (in translation) 'Environmentally-oriented Strategies of Business Concerns - Applications in Big Banks' (Hansen, 1992), drew on a detailed environmental survey of five Swiss, four German, and three Austrian, banks.

\section{Banks, Property Contamination, and The Law}

CERCLA in the USA, in one form or another, seems to be here to stay. And it should not be forgotten that this is where the earliest bank/environment consciousness began to develop. In any event, legislative measures, Acts of

*As can be seen from the detailed Table of his own and others' results compiled by the Author and generously available from him at the address given at the head of this paper. - Ed. parliament, and politicians' pronouncements — as often as not the bane of many a bank's legal department - are an unavoidable part of the scenario. To illustrate this, here are some recent developments on the subject of the (in bankers' eyes) all-important issue of property contamination, which currently hampers lending in many countries.

1) In May 1993, the federal district court for the southern district of the State of Georgia, USA, re-heard the Fleet Factors case in the light of an April 1992 US Environmental Protection Agency (EPA) rule (EPA, 1992) which was intended to clarify activity that would be permissible to lenders. The said rule was partly the result of the furore in the US banking community which greeted the legal interpretation of three little words in the original judgement: 'capacity to influence' (see above). The court found Fleet Factors liable for Superfund clean-up costs of some US\$1 million, on the basis that the action of its agents had voided the statutory exemption granted to secured creditors under CERCLA (Financial Times Environmental Liability Report [FT ELR], 1993a).

2) In October 1993 the British environment minister, in a speech to the British Bankers' Association, expressed his opposition to EC environmental liability schemes and said that he did not see the US Superfund programme* as a model for action in British banking circles. At the same time he stressed the positive, deterrent, effect of the Superfund. Banks had an important role to play in encouraging wider confidence and environmental awareness among their customers, as well as in providing funds (FT ELR, 1993b).

3) In February 1994 the US Circuit Court of Appeals for the District of Colombia threw US banks into confusion by ruling that the EPA had exceeded its authority when it issued its April 1992 Rule. Secured creditors would now be considered owners of contaminated land under CERCLA. The US Department of Justice and the American Bankers Association subsequently filed petitions for a re-hearing (FT ELR, 1994a, 1994b).

4) In March 1994 the EC approved an agreement between the Dutch Government and the Dutch National Investment Bank NV (NIB) to grant partial state guarantees on NIB loans to companies wishing to undertake voluntary clean-up of their own premises, but unable to secure finance to do so (FT ELR, 1994c).

5) A definition of 'financial institution' - effectively encompassing all banks, financial institutions, friendly societies, and financial corporations - was introduced into the Environmental Protection (General Amendment) Act of the Australian State of Victoria, which came into force in June 1994. This amending legislation, based largely on US Superfund law, limits the liability of financial institutions to cases of mortgagees in possession, where pollution occurred after the relative property was taken over, and to cases of (only broadly defined) 'environmental hazard'. Legal experts believe, however, that adequate due diligence procedures would constitute the only real defence (FT ELR, 1994d, 1995b).

* In response to our enquiry about this the Author replied 'US Superfund: one of the new, central components of CERCLA [1980], under which a fund (initially US\$1.6 thousand millions, financed by taxes on petroleum products and certain chemicals) was set up. This was to be used to clean up land-based sites, pending cost recovery actions against responsible parties.' [See USA (1992)]. - Ed. 
6) The Bill intended to re-authorize CERCLA was finally abandoned by the US Congress in October 1994, throwing the US lending industry into confusion (FT ELR, 1994e, 1994f).

7) A policy document entitled 'Framework for Contaminated Land' was published by the UK Department of the Environment and the Welsh Office in November 1994; this followed the review of contaminated land and associated liabilities (in March 1993), and the simultaneous withdrawal of the widely-criticized proposals under Section 143 of the Environmental Protection Act 1990. In response to pressure from the financial sector, the Government included certain provisions in the Framework document, which go some way towards clarifying the position of banks when judged against the 'cause or knowingly permit' test, instrumental in the definition of the primary responsible party - responsible, that is, for the contamination. However, under Part II of the Environmental Bill (December 1994), there seems to be less comfort for the financial services sector. In a brief issued in March 1995 , the British Bankers' Association commented that under this legislation, should lenders be held liable for environmental damage caused by their borrowers, 'this could have a dramatic effect on the availability of finance for many small businesses, such as dry-cleaners, printers, petrol stations, farms, and agrochemical suppliers, or virtually any company which handles materials that are hazardous to the environment' (FT ELR, 1994g, 1995a, 1995b).

8) In April 1995 the Ontario, Canada, banking community appeared to be near to securing a Standard Agreement Concerning Environmental Investigations from the provincial Ministry of Environment and Energy. This would break new ground in the definition of activities which lenders would be permitted to undertake, while dealing with borrowers' contaminated property. Lobbying on this subject has been taking place in all Canadian provinces (FT ELR, 1995b).

9) In May 1995, following an announcement by the US Environmental Protection Agency of a package of administrative reforms to the Superfund hazardous substance clean-up programme, which was intended to ease liability barriers, The Bankers Roundtable of Washington published the results of a survey conducted among its own members (FT ELR, 1995c), representing the 125 largest US banking corporations. Respondents showed an everincreasing concern about environmental problems, particularly those surrounding contaminated property. Poignantly:

$94 \%$ had increased the use of loan covenants $r e$ borrowers' environmental compliance; and

- $95 \%$ had been forced to spend money on environmental remediation for property use or disposal.

Property contamination is indeed a troublesome part of the bank/environment equation.

\section{ENVIRONMENTAL ASSESSMENT}

As yet, there is no consensus among banks about the format of environmental assessment (EA). There are a number of models, most of them now linked to the creditgiving processes. The principles of environmental impact analysis or assessment (EIA), an early designation usually associated with a particular project, have been developed and transformed as thinking on the whole subject has pro- gressed. In fact this terminology dates from 1969, when the US Congress approved the National Environment Policy Act (NEPA). This Act established a policy of using 'all practical means and measures... to create and maintain conditions under which man and nature can exist in productive harmony, and fulfill the social, economic, and other, requirements of present and future generations of Americans'. The EIA process, designed particularly to promote public participation, was closely associated with this policy.

NEPA provided for the creation of a Council for Environmental Quality (CEQ), in order to assist agencies to comply with the legal requirements of the EIA process. This process consists, broadly, of two levels of reporting. The environmental assessment (EA) is a concise public document containing a brief environmental analysis and a discussion of alternatives. If analysis is favourable. EA serves as a basis for a finding of no significant impact (FONSI). If significant environmental impacts seem - at any stage - likely, then the agency proceeds to the second reporting level: the environmental impact statement (EIS). Whenever an EIS is prepared, a record of decision (ROD) must be drafted (USA, 1992).

Apart from such terms as EA, EIA, EIS, environmental credit risk-analysis, and environment audit, the reader may, more recently, have heard of environmental risk rating (ERR). This is a process which is being designed with the depositor (in the case of banks) or the investor in mind. There are also a number of models. Significantly, in early 1995, the Centre for the Study of Financial Innovation (CSFI) in London, England, completed an ERR of Scottish Nuclear, the state-owned nuclear power utility which faced possible privatization and was keen to establish its financial credentials. The rating was essentially a reflection of the potential for environment-related loss, expressed on an alphabetical scale, in the manner of a credit rating. Eleven categories of environmental risk were identified: regulation; safety/environment; decommissioning; radioactive waste; provisioning policy; legal; suppliers; external pressures; management; business prospects; and financial condition.

After the study, on the basis of which Scottish Nuclear was awarded the third-highest mark on a seven-points scale, the CSFI panel (which included experts in finance, law, nuclear technology, environmental auditing, and risk analysis) concluded:

'It will be up to the financial markets to judge how useful an environmental risk rating is in financial decisionmaking. We believe it highlights an important aspect of a company, and one which is increasingly sensitive to the outside pressures of regulation and public opinion - in other words, forces which are to some extent beyond management control. (...)' (CSFI, 1995).

Such studies will require banks, in the not-too-distant future, to get their sums right, which they are beginning to position themselves well to do.

\section{BANKS AND THE BIOSPHERE}

It is clear from the above that most of the recent advances in the bank / environment / development conundrum have been made by the financial communities of the developed world. At the other end of the scale, in the former Soviet Union, even well-intentioned banking institutions are immobilized by legal limbo: if property ownership is not 
anchored in legislation, pollution control has not got a chance. The closest thing to Russian environmental banking, as explained to this writer, during a visit to Moscow in August 1994, was a service provided by Orbita Bank, in the form of bridging finance, during the ponderous process of application for a grant from the Moscow Ecological Fund. Approval of such allocations takes place once a year. The Russian Federal Ecological Fund (RFEF) is hamstrung by the deliberations of up to 38 different ministries and departments of State. The formation and finance of these 'ecological' funds has now been explained in the 1993 National Report of the State of Environment of the Russian Federation, and the difficulties of maintaining the RFEF, have been admitted (Russia, 1993). Now that the truth is at last being told, discussion of decentralized funding alternatives will, hopefully, follow.

And then there is Africa! In banking circles, President Nelson Mandela, of the Republic of South Africa, holds the key to the whole of sub-Saharan Africa. Measured by 'Tier One capital', the size of the African contribution to the world banking community is puny, with the six banks (all South African) in The Banker's Top 1,000 listing accounting for less than $0.5 \%$ of the global total. David Hughes (of UK lawyers Wilde Sapte) is quoted as saying: 'If South Africa fails, then the whole of sub-Saharan Africa may be consigned to the dustbin (in investment terms)'. Strong language. But if investment ceases, the only alternative to the begging-bowl is self-help (The Banker, 1994).

Contentiously - but no less obviously - many other factors are not conducive to bankers putting the environment at the top of their list of priorities. These include: state ownership (e.g. Cuba); threat of bankruptcy (the bad debts of Japanese banks are currently estimated at some 80 'trillion' (million million) yen); the privatization process (France, Italy); murder of senior bankers (more than 46 such deaths in Russia in the last three-and-a-half years); drought, famine, and anarchy (Somalia); and civil war (Afghanistan, Liberia, Sri Lanka, and the former Yugoslavia).

Nevertheless, a start has been made, and wherever environment gets back onto an agenda, development should not be far behind. Is it too much to hope that, the next time Robin Hood and Maid Marion meet a banker riding through their ecological domain of a successfully reconstituted Sherwood Forest, they will now feel more inclined to invite him to their bower? They may even find that he will bring something with him which goes well with a nice pot of green tea.

\section{ACKNOWLEDGEMENTS}

The present writer is indebted to the American Bankers Association, Washington, the UN Environment Programme (UNEP), Geneva, the International Chamber of Commerce (ICC), Paris, GHK International, London, and the many banks and bankers, around the world, who participated in his own survey, for having made available their respective contributions to the information given in this paper. A wealth of ancillary information was received from the said respondents, including copies of environmental legislation in Arabic (Oman), Chinese (Taiwan), Hungarian, and Polish. While this background material (where necessary duly translated) showed that banks were not yet seen by legislators as a part of the process (except as potential 'deep-pocket' victims of CERCLA in the USA), it nevertheless contributed significantly to this layman's understanding of the subject.
Special words of appreciation are due to Dr Robert J.A. Goodland, of the World Bank, and Professor Nicholas Polunin, Editor of this Journal. Dr Goodland's tireless efforts and initiatives in this field have been a source of inspiration, and his timely words of advice a great boon. It was Professor Polunin who first exercised his enthusiasm and ability to fire our imagination, then generated the spark for this study. Both of these experts patiently and compassionately assisted the present writer to bridge the gap between the dry science of commercial banking and the novel (to him) challenges of Environment and Development.

\section{SUMMARY}

No-strings-attached lending is anathema to the serious commercial banker, who sees only a wafer-thin line between such 'lending' and the un-bank-like practice of giving (non-returnable) grants. Such doubts, indeed, are not confined to the banking industry. In the face of homegrown problems of unemployment or health-care, for instance, democratically elected governments of donor countries are finding themselves under increasing pressure from their voters to cut back on bilateral assistance to hopelessly indebted taker-states. Multilateral lending and development institutions are facing an uncertain future, trapped in the vicious circle of bad debts that are all-too-steadily increasing, capital and funding quotas that are failing to materialize (eyes are currently on the US Congress), and borrowing that is becoming ever-more expensive. The African Development Bank is faltering; a Middle East Development Bank is in danger of being stillborn. The World Bank has recently been trying bravely to redress the balance: it has created a 'multilateral debt facility' for the most severely-indebted countries, and devised a numerical scale of national well-being that is more appropriate for the measurement of ecologically sustainable development than GNP per head of population. While these initiatives should not be belittled, good ideas are too often murdered by gangs of ugly facts.

Three years ago, at UNCED in Rio, great divides very quickly became evident: north $v$. south; givers $v$. takers; even environment $v$. development. Whenever funding was discussed, another gap appeared: How much? $v$. How on earth? And while astronomical figures were produced in response to the former question, the latter - to this day has not been satifactorily answered. True, percentages of GNPs were 'pledged' at the time by developed countries, and GEF was touted as the answer to the developing world's prayers. But it was not to be. And why not? One of the reasons, the present writer argues, was that a key fraternity in the world's business community did not take part in the planning process.

International bank lending is now measured in US trillions (millions of millions) of dollars, and the global capital market in tens of such trillions. Central banks, commercial banks, and even private banks, world-wide, have a part to play in the development of every single financial transaction that services this huge sector. Banks - at any rate in the developed world - are now learning that they can, and indeed must, become involved in the conservation of The Biosphere on one hand*, and in the furthering of the development process on the other.

* As perennially adjured for everybody in this Journal and our International Conferences on Environmental Future (e.g. Surviving With The Biosphere [Polunin \& Burnett, 1993]). - Ed. 
Internal studies, leading, for example, to energy-saving, are being translated into advice for customers; EIAs, in line with local environmental requirements, are being created, with a view to their eventually becoming a sine qua non in all lending and investment operations. Banks are cutting their way through the thickets of environmental law as applied, for example, to the situation in which they suddenly become unwilling possessors (by way of mortgage) of polluted real estate. Most exciting, perhaps, is the vision that, after assembling a sufficient store of knowledge on the subject, local banks in developing countries will be prepared and able to take over the role of multilateral institutions in financing innovative development projects in their own environments. This paper is a measure of the progress in this direction which banks have made to date.

'How can you say the poor are not credit-worthy?' was a rhetorical question recently posed by $\mathrm{Mr}$ Muhammad Yunus, founder of the Grameen Bank, which is acknowledged as the world's leader in 'micro-lending' (to the leastprivileged families of one the world's poorest countries, Bangladesh). 'The basic question', he ventured, 'is whether banks and credit institutions are people-worthy'.

\section{ACRONYMS AND ABBREVIATIONS}

$\begin{array}{ll}\text { ACBE } & \text { Advisory Committee on Business and the Environment } \\ \text { BIS } & \text { Bank for International Settlements } \\ \text { CB } & \text { Central Bank } \\ \text { CEQ } & \text { Council for Environmental Quality } \\ \text { CERCLA } & \text { Comprehensive Environmental Response, Compensation } \\ & \text { and Liability Act } \\ \text { CFCs } & \text { Chlorofluorocarbons } \\ \text { CSFI } & \text { Centre for the Study of Financial Innovation } \\ \text { EA } & \text { Environmental Assessment } \\ \text { EBRD } & \text { European Bank for Reconstruction and Development } \\ \text { EC } & \text { European Community } \\ \text { EIA } & \text { Environmental Impact Assessment (or Analysis) } \\ \text { EIS } & \text { Environmental Impact Statement } \\ \text { EPA } & \text { Environment Protection Agency } \\ \text { ERR } & \text { Environmental Risk Rating } \\ \text { ESAP } & \text { Environmental Self-assessment Program } \\ \text { FONSI } & \text { Finding of No Significant Impact } \\ \text { FT ELR } & \text { Financial Times Environmental Liability Report } \\ \text { GEF } & \text { Global Environmental Facility } \\ \text { GEMI } & \text { Global Environmental Management Initiative } \\ \text { GHK } & \text { Gilmore, Hankey \& Kirk International } \\ \text { GNP } & \text { Gross National Product } \\ \text { ICC } & \text { International Chamber of Commerce } \\ \text { IPCC } & \text { Intergovernmental Panel on Climate Change } \\ \text { MICCI } & \text { Malaysian International Chamber of Commerce and } \\ & \text { Industry } \\ \text { NEPA } & \text { National Environment Policy Act } \\ \text { NGO } & \text { Nongovernmental Organization } \\ \text { NIB } & \text { [Dutch] National Investment Bank } \\ \text { RFEF } & \text { Russian Federal Ecological Fund } \\ \text { ROD } & \text { Record of Decision } \\ \text { UNCED } & \text { United Nations Conference on Environment and } \\ & \text { Development } \\ \text { UNEP } & \text { United Nations Environment Programme } \\ & \end{array}$

\section{REFERENCES}

AMERICAN BANKERS AsSOCIATION (1991). Statement: Lender Liability under Superfund. Survey by the New Jersey Bankers Association, Washington, DC, USA, pp. 4-5.

BANKER, THE (London) (1994). Issue of December, p. 66.

BANKER, THE (London) (1995). Issue of July, pp. 135-207.

CSFI (1995). An Environmental Risk Rating for Scottish Nuclear. Available from CSFI, 18 Curzon Street, London W1Y 7AD, England, UK: [not available for checking].

EPA (1992). Comprehensive Environmental Response, Compensation and Liability Act (CERCLA). Environment Protection Agency: Vol. 57, Nr 83, Part XI, 57 FR 18344, 29. r.1992.

FinanCial Times (1995). Issue of 30 August, p. 3.

Financial Times Environmental Liability Report (FT ELR) (London) (1993a). Issue 001 of September, p. 16.

FT ELR (1993b). Issue 002 of October, p. 17.

FT ELR (1994a). Issue 006 of February, p. 18.

FT ELR (1994b). Issue 008 of April, p. 18.

FT ELR (1994c). Issue 009 of May, p. 16.

FT ELR (1994d). Issue 011 of July, p. 18.

FT ELR (1994e). Issue 014 of October, p. 3.

FT ELR (1994f). Issue 015 of November, pp. 16-7.

FT ELR (1994g). Issue 016 of December, pp. 15-7.

FT ELR (1995a). Issue 017 of January, pp. 16-7.

FT ELR (1995b). Issue 020 of April, pp. 15-8.

FT ELR (1995c). Issue 022 of June, p. 16.

GHK INTERNATIONAL LTD (1994). Environmental Training for Bankers in Central and Eastern Europe - Task 1: Report of Survey, Spring 1994. Available from GHK International Ltd., 30 St Paul's Square, Birmingham B3 1QZ, England, UK: 57 pp., 5 appendixes.

GoODLAND, R.J.A. (1992). Environmental priorities for financial institutions. Environmental Conservation, 19(1), pp. 9-21, 5 tables and 10 annexes.

HanSEN, S.M. (1992). Umweltorientierte Unternehmensstragien Ansätze in Grossbanken: Kapitel 6 Grossbanken und Umwelt. Hochschule St Gallen, Switzerland: pp. 327-79.

MCCAMMON, A.L.T. (1994). Environment and development: key role for banks? Environmental Conservation, 21(4), pp. 291-3.

Polunin, N. \& BurnetT, Sir J. (1993). Surviving With The Biosphere: Proceedings of the Fourth International Conference on Environmental Future... Edinburgh University Press, 22 George Square, Edinburgh, Scotland, UK: xxii +572 pp., illustr., appendixes $\&$ indexes.

Russia (1993). State of Environment of The Russian Federation 1993 National Report. Ministry for Environment Protection and Natural Resources of The Russian Federation: Translation, Image Publishing House, Moscow, Russia, 1994: p. 251: [volume not available for checking].

UNCED (1993). Report of the United Nations Conference on Environment and Development, Rio de Janeiro, 3-14 June 1992 United Nations, New York, NY, USA: Volume I Resolutions Adopted by the Conference. Annex II Agenda 21.33.13, p. 414.

UNEP (1995). UNEP Global Survey: Environmental Policies and Practices of the Financial Services Sector January 1995. United Nations, New York, NY, USA: 12 pp., 4 appendixes.

USA (1992). United States of America National Report [to] UNCED 1992. Washington, DC, USA: $372 \mathrm{pp.}$

WILDE SAPTE (1991). Lenders' Liability for Environmental Damage. Available from Wilde Sapte, Queensbridge House, 60 Upper Thames Street, London EC4V 3BD, England, UK: $10 \mathrm{pp}$. (typescript). 